\title{
Shared Curricula and Competencies in One Health and Health Professions Education
}

\author{
Roxanne J. Larsen ${ }^{1,2}$ (ID \\ Accepted: 26 October 2020 / Published online: 10 November 2020 \\ (C) The Author(s) 2020
}

\begin{abstract}
Globally, health professions education programs have similar course content and expectations for learners. One Health core competencies are shared by many health professions accreditation bodies. These competencies provide a framework which can guide professional programs in a world with emerging zoonotic diseases, a growing interface between humans and animals, and ongoing impacts from climate change. By focusing on shared outcomes, we can better prepare our learners for a more interdisciplinary practice of medicine and science. Fundamental courses, like gross anatomy, can be a uniting thread. A general overview of anatomy courses in medical and veterinary programs is provided.
\end{abstract}

Exploring the connections among human, animal, and environmental health is a key component of One Health approach (e.g., One Health Initiative, One Health Commission) [1, 2] and should be incorporated into health professions education (HPE) programs and their curricula for all levels and fields of health professional learners. The One Health approach provides a framework of core competencies including domains such as management, communication and informatics, values and ethics, leadership, team and collaboration, roles and responsibilities, and systems thinking [3, 4]. These shared competencies are especially important in guiding our health professions curricula in a world with emerging zoonotic diseases, the growing interface between humans and animals, and the ongoing impacts from climate change.

There has been a historical connection to the One Health approach in science and medicine, which contributed to the birth and development of many basic science disciplines including anatomy, physiology, and immunology (Fig. 1). The history of One Health begins as early as the time of the Egyptians and continued with several growth spurts in public health and comparative medicine. Eventually, the continued

Roxanne J. Larsen

rlarsen@umn.edu

1 Department of Veterinary and Biomedical Sciences, College of Veterinary Medicine, University of Minnesota, St. Paul, MN, USA

2 Medical Education Division, Duke University School of Medicine, Durham, NC, USA advances in medicine and technology allowed for more comparative and interventional methods to be employed $[5,6]$.

Along with a shared history, there are shared professional competencies and/or accreditation standards across a variety of health professional programs (Table 1). The programs included in this brief overview are the American Veterinary Medical Association (AVMA) Council on Education (COE) Accreditation Policies and Procedures, requirements for Standards of Accreditation (7.9. Standard 9, Curriculum) [7]; the Association of American Veterinary Medical Colleges (AAVMC) Competency-Based Veterinary Education (CBVE) competency domains and framework [8]; the Association of American Medical Colleges (AAMC) and the Liaison Committee on Medical Education (LCME) accreditation standards (Standard 7, Curricular Content) [9]; and One Health core competency domains as best summarized in Frankson et al. [3]. For brevity, the core competencies of other health profession disciplines and their accreditation bodies (e.g., osteopathic, nursing, allied health) were not included in this table, but they also emphasize similar topics. Although there are many shared competencies, we should also be asking ourselves if our current curricula provide awareness about the blending boundaries between human and animal health, and the potential impacts of global connectedness on healthcare systems. As you can see, these key features are missing from these broader curricular competencies summarized as "Common themes" in Table 1.

As an example of a place to start developing One Health approaches early in HPE programs, I focused on anatomy courses in medical and veterinary schools. Drawing from 


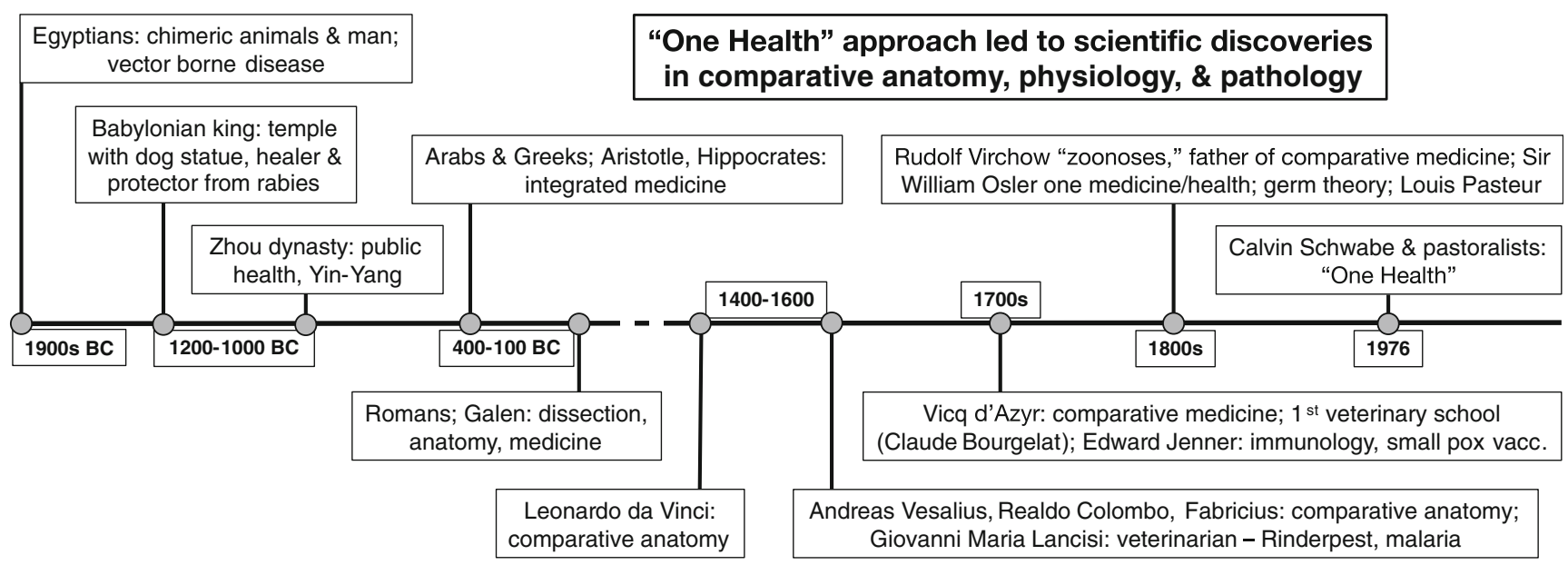

Fig. 1 History of the One Health approach. Timeline compiled and modified from Vergis et al. [5] and Capua and Cattoli [6]

my own experiences [10] and fellow anatomy educators [11-13], a general comparison between veterinary and medical anatomy courses outlining how anatomy is delivered, including a description of the primary educators and other instructors, is presented (Table 2). Table 2 also provides a description of the primary focus (e.g., in veterinary anatomy there is typically a semester on small animal/carnivore anatomy, and a semester on large animal/ungulate anatomy), additional concepts listed in order of emphasis, and which topics students found to be most similar or helpful in understanding the anatomy of their discipline. Student input was collected through my own experiences and observations when teaching a variety of regional anatomy courses and dissection labs, and through direct communication with students. Also noted is the observation of an increasing trend where courses focus on clinically relevant anatomy, which may be due to reductions in contact hours and the continual curricular reform and revision efforts underway at many institutions. In the end
Table 1 Shared competencies and/or accreditation standards across a few representative health professions programs. Competencies and standards were gathered from the respective accreditation bodies or institutions and condensed and summarized. AVMA COE American Veterinary
Medical Association Council on Education; $A A V M C C B V E$ Association of American Veterinary Medical Colleges Competency-Based Veterinary Education; AAMC LCME Association of American Medical Colleges, Liaison Committee on Medical Education

\begin{tabular}{|c|c|c|c|c|}
\hline AVMA COE & AAVMC CBVE & AAMC LCME & One Health & Common themes \\
\hline $\begin{array}{l}\text { Problem solving, theory and } \\
\text { practice of medicine, } \\
\text { diagnostic methods, and } \\
\text { interpretation }\end{array}$ & $\begin{array}{l}\text { Clinical reasoning, } \\
\text { decision making, } \\
\text { critical thinking, } \\
\text { problem solving }\end{array}$ & $\begin{array}{l}\text { Critical judgment and } \\
\text { problem solving, } \\
\text { diagnosis, and treatment } \\
\text { planning }\end{array}$ & $\begin{array}{l}\text { Problem solving, change } \\
\text { makers }\end{array}$ & $\begin{array}{l}\text { Critical judgment, problem } \\
\text { solving, clinical reasoning, } \\
\text { decision making }\end{array}$ \\
\hline Contribution to teams & Collaboration, teams & IPE collaboration, teams & Teams, collaboration & IPE collaboration, teamwork \\
\hline Communication & Communication & Communication & Communication & Communication \\
\hline $\begin{array}{l}\text { Biological principles, making and } \\
\text { applying medical judgment }\end{array}$ & $\begin{array}{l}\text { Scholarship, } \\
\text { evidenced-based prac- } \\
\text { tice }\end{array}$ & $\begin{array}{l}\text { Scientific knowledge, } \\
\text { methods, and research }\end{array}$ & $\begin{array}{l}\text { Systems thinking, policy, } \\
\text { awareness of big picture }\end{array}$ & $\begin{array}{l}\text { Evidenced-based practice, } \\
\text { research, scholarship, systems } \\
\text { thinking }\end{array}$ \\
\hline Ethical and professional conduct & $\begin{array}{l}\text { Professionalism, ethical } \\
\text { reasoning, leadership }\end{array}$ & Medical ethics, values & $\begin{array}{l}\text { Values, ethics, } \\
\text { professionalism, leadership }\end{array}$ & $\begin{array}{l}\text { Ethics, values, professionalism, } \\
\text { leadership }\end{array}$ \\
\hline $\begin{array}{l}\text { Individual and population } \\
\text { management }\end{array}$ & $\begin{array}{l}\text { Individual and population } \\
\text { care, welfare, } \\
\text { management }\end{array}$ & $\begin{array}{l}\text { Individual and population } \\
\text { health }\end{array}$ & $\begin{array}{l}\text { Management of teams and } \\
\text { resources }\end{array}$ & $\begin{array}{l}\text { Individual and population care, } \\
\text { welfare, management, } \\
\text { team/resource management }\end{array}$ \\
\hline $\begin{array}{l}\text { Patient health and welfare, public } \\
\text { health }\end{array}$ & $\begin{array}{l}\text { Public health, global } \\
\text { perspective, education }\end{array}$ & $\begin{array}{l}\text { Diagnosis, prevention, } \\
\text { reporting of common } \\
\text { society problems }\end{array}$ & $\begin{array}{l}\text { Broader awareness, One } \\
\text { Health approach, diplomacy }\end{array}$ & $\begin{array}{l}\text { Awareness of healthcare } \\
\text { disparities, public health }\end{array}$ \\
\hline Diversity and inclusion & $\begin{array}{l}\text { Communicates with } \\
\text { diverse clients, } \\
\text { colleagues, and public }\end{array}$ & Cultural competence & $\begin{array}{l}\text { Diverse teams, cultural } \\
\text { competence }\end{array}$ & $\begin{array}{l}\text { Cultural competence, diversity, } \\
\text { and inclusion }\end{array}$ \\
\hline $\begin{array}{l}\text { Testing and record management, } \\
\text { treatment plan, and referral }\end{array}$ & $\begin{array}{l}\text { Financial and practice } \\
\text { management, legal and } \\
\text { regulatory requirements }\end{array}$ & & & $\begin{array}{l}\text { Management of records and } \\
\text { finances, awareness of legal } \\
\text { and regulatory requirements }\end{array}$ \\
\hline
\end{tabular}


Table 2 A general overview of the delivery of anatomy and focus of anatomy content at veterinary and medical schools. This table is compiled from my own experiences as an educator [10] and from other anatomy educators [11-13]

\begin{tabular}{|c|c|c|}
\hline & Veterinary schools & Medical schools \\
\hline \multicolumn{3}{|l|}{ Delivery } \\
\hline Primary anatomy educators are: & DVMs, PhDs (biological disciplines) & $\mathrm{PhDs}$ (anthropologists), MDs \\
\hline Additional educators are: & Veterinary technicians, DVMs (surgeons) & Graduate students, MDs (surgeons) \\
\hline \multicolumn{3}{|l|}{ Content } \\
\hline Anatomy primarily focused on: & Typical pathways/patterns in carnivores and ungulates & Typical pathways/patterns in humans \\
\hline \multirow[t]{4}{*}{$\begin{array}{l}\text { Additional concepts of focus, listed } \\
\text { in order of emphasis: }\end{array}$} & $\begin{array}{l}\text { 1) Vertebrate anatomy (e.g., human; domestic, } \\
\text { agricultural, exotic animals) }\end{array}$ & $\begin{array}{l}\text { 1) Common variations (emphasis on surgical } \\
\text { scenarios) }\end{array}$ \\
\hline & 2) Species differences & 2) Clinical anatomy* \\
\hline & 3) Clinical anatomy* & 3) Integration of structure and function \\
\hline & 4) Integration of structure and function & 4) Vertebrate anatomy (e.g., primate, general mammal) \\
\hline $\begin{array}{l}\text { Students found these topics most } \\
\text { similar: }\end{array}$ & $\begin{array}{l}\text { Human anatomy helpful in understanding } \\
\text { neuroanatomy and musculoskeletal anatomy }\end{array}$ & $\begin{array}{l}\text { Vertebrate anatomy helpful in understanding } \\
\text { neuroanatomy musculoskeletal anatomy }\end{array}$ \\
\hline
\end{tabular}

*Clinical anatomy is quickly becoming the primary emphasis in both

however, the similarities in HPE program curricula and the pre-clinical or basic science course content, particularly anatomy, outnumber the differences.

Anatomy can be used as an early platform to bring health professional learners together in an applied and meaningful way, as it is taught early in the curriculum in almost all programs. A handful of multidisciplinary universities that currently hold interprofessional education (IPE) and One Health sessions with medical, veterinary, and other health professional students include the following: Tufts University Cummings School of Veterinary Medicine and School of Medicine (Comparative Anatomy Exchange Day, An Interprofessional Tufts One Health Event), and the University of Pennsylvania School of Veterinary Medicine and Perelman School of Medicine (Penn Inter-Health School Anatomy Exchange). These types of educational activities are most often hands-on or applied sessions, and many of these interprofessional events were initiated by student clubs or organizations associated with public health, global health, or One Health. A key alliance that has helped connect these student groups globally is the International Student One Health Alliance (ISOHA) [14], which is associated with the One Health Commission [2]. Many of these clubs facilitate sessions that highlight comparative anatomy as a way to connect with other health professional students.

Educational activities meant to bring learners together should follow the general trends practiced in IPE and active learning [15], where they are (1) focused on shared concepts and experiences; (2) best carried out in small groups; (3) simple and repeatable; and (4) highlight the similarities among various health professionals. The professional traits emphasized during IPE are often already imbedded in the overarching curriculum of traditional HPE programs and also align with One Health competencies. Many may ask if these types of sessions are actually feasible. We do have limited time to deliver content, increasing demands on faculty time and effort, recommendations to reduce cognitive overload for our learners, and potentially lengthy distances between the variety of HPE programs. However, we can overcome some of these potential barriers by using technology to our advantage with tools similar to those we all are currently employing during the COVID-19 pandemic. For example, video conferencing software (e.g., Zoom, Microsoft Teams, Google Classroom) [16], video recording software (e.g., Fliprid, VoiceThread, Screencast-O-Matic), polling applications (e.g., Poll Everywhere, ChimeIn 2, Mentimeter), virtual anatomy applications (e.g., veterinary: IVALA through the Veterinary Information Network, The Glass Horse and Dog through Science in 3D; human: Visible Body, BioDigital Human), and even 3D printing of difficult to dissect structures and regions $[10,17]$. Learners are relatively well equipped to navigate the new technologies and ways of communicating. We as educators now need to open ourselves up to training in these fields. We also need to embrace the healthcare models of the future. Additionally, we cannot forget that all stakeholders (including students) should be a part of the discussion if these types of events are going to be successful. Buy-in at multiple levels is key not only for the initial success of an event, but also for the sustainability of the overall concept of One Health in HPE. The intended end goal of IPE events in this context would be to allow learners from a variety of HPE programs to share knowledge, experiences, and perspectives in healthcare, so that they can be successful in meeting the ever-changing needs of a connected global population.

In sum, educators should take advantage of active-learning settings (i.e., laboratory-based course components, team- 
based learning); emphasize communication, collaboration, and problem-solving skills; foster an educational environment that focuses on knowledge of transdisciplinary sciences; promote awareness of a broad-based global health perspective and social and cultural aspects of health; and help develop professionals that have the skills to interact with diverse communities and can critically evaluate health policies. All of these factors highlight the need for One Health as an underlying theme in our HPE systems, so that we can all better understand the connectedness of humans, animals, and the environment. Now more than ever our developing health professionals need a shared framework that will allow them to have early and meaningful interactions with each other. These early interactions will allow them to engage and better understand diverse perspectives, which ultimately influences their abilities to provide global healthcare and practice global medicine.

Acknowledgments The author thanks M. McNulty, R. Lufler, J. Castellot, and Z. Throckmorton for insightful discussions about veterinary and medical education (as a part of a symposium at the American Association for Anatomy conference in 2019, Functional Comparative Anatomy as a Platform for Interprofessional Education). The author also thanks P. Larsen for reviewing this manuscript in its early stages.

Author's Contributions RJ Larsen had the idea for the article, performed the literature search, compiled and created the tables, created the figure, and drafted and critically revised the work.

Data Availability Not applicable

\section{Compliance with Ethical Standards}

Conflict of Interest The author declares that she has no conflict of interest.

Code Availability Not applicable

Open Access This article is licensed under a Creative Commons Attribution 4.0 International License, which permits use, sharing, adaptation, distribution and reproduction in any medium or format, as long as you give appropriate credit to the original author(s) and the source, provide a link to the Creative Commons licence, and indicate if changes were made. The images or other third party material in this article are included in the article's Creative Commons licence, unless indicated otherwise in a credit line to the material. If material is not included in the article's Creative Commons licence and your intended use is not permitted by statutory regulation or exceeds the permitted use, you will need to obtain permission directly from the copyright holder. To view a copy of this licence, visit http://creativecommons.org/licenses/by/4.0/.

\section{References}

1. One Health Initiative http://www.onehealthinitiative.com/index. php. Accessed 1 April 2020.

2. One Health Commission https://www.onehealthcommission.org/. Accessed 1 April 2020.

3. Frankson R, Hueston W, Christian K, Olson D, Lee M, Valeri L, et al. One Health Core competency domains. Front Public Health. 2016;4:192.

4. Togami E, Gardy JL, Hansen GR, Poste GH, Rizzo DM, Wilson ME, Mazet JA. Core competencies in One Health education: what are we missing. Perspectives - Natl Acad of Med, Washington, DC 2018;1-12.

5. Vergis J, Das DP, Suryawanshi RD, Mamta N, Pankaj D, Deepthi V. One Health approach: veterinary perspectives in global and Indian context. Adv Anim Vet Sci. 2014;2(4S):11-16.

6. Capua I, Cattoli G. One Health (r)evolution: learning from the past to build a new future. Viruses. 2018;10(12):725.

7. American Veterinary Medical Association (AVMA) Council on Education (COE) Accreditation Policies and Procedures https:// www.avma.org/education/accreditation/colleges/coe-accreditationpolicies-and-procedures-requirements. Accessed 1 April 2020.

8. Association of American Veterinary Medical Colleges (AAVMC) Competency-Based Veterinary Education (CBVE) framework https://www.aavmc.org/competencybasedveterinaryeducation/ cbve-framework.aspx. Accessed 1 April 2020.

9. Association of American Medical Colleges (AAMC) Functions and Structure of a Medical School, Liaison Committee on Medical Education (LCME) Standards https://lcme.org/publications/\# Standards. Accessed 1 April 2020.

10. Larsen RJ. Learning together about anatomical variation across species: examples from veterinary and medical education. FASEB J. 2019;33(S1):325.2.

11. Castellot J, Afifi L. Opportunities and challenges for interprofessional One Health education. FASEB J. 2019;33(S1):325.1.

12. McNulty MA, Mussell J, Lufler R. Similarities between veterinary and human medical anatomy curricula and educators. FASEB J. 2019;33(S1):440.6.

13. Throckmorton Z. How comparative anatomy provides insight into human anatomy. FASEB J. 2019;33(S1):325.3.

14. International Student One Health Alliance (ISOHA) https://www. onehealthcommission.org/en/leadership board of directors/ students_for_one_health_soh_news/. Accessed 1 April 2020.

15. Edwards RA, Venugopal S, Navedo D, Ramani S. Addressing needs of diverse stakeholders: twelve tips for leaders of health professions education programs. Med Teach. 2019;41:17-23.

16. Kogan M, Klein SE, Hannon CP, Nolte MT. Orthopaedic education during the COVID-19 pandemic. J Am Acad Orthop Surg. 2020;28:e456-64.

17. Fredieu JR, Kerbo J, Herron M, Klatte R, Cooke M. Anatomical models: a digital revolution. Med Sci Educ. 2015;25(2):183-94.

Publisher's Note Springer Nature remains neutral with regard to jurisdictional claims in published maps and institutional affiliations. 